\title{
The aesthetic ideology of Juliana v. United States and its impact on environmentally engaged citizenship
}

\author{
Dana Neacşu ${ }^{1,2,3}$
}

Accepted: 22 October 2021 / Published online: 24 November 2021

(c) AESS 2021

\begin{abstract}
Following Wittgenstein's call to imagine law as a way of life (1958), we can envisage environmental law and environmentalism as a way of living beautifully. Employing George Santayana's aesthetic theory (1896, 1905, 1910), this article explores environmentally engaged citizenship as more than a mere ideological manifestation of subjectivity. A multifaceted relationship between individuals and their environment, it manifests itself through their ideology, political subjectivity, but also through aesthetic subjectivity. Using Juliana $v$. USA as a case study, this article examines civic engagement taking into consideration its deeply ideological and aesthetic nature.
\end{abstract}

Keywords Environmentally engaged citizenship $\cdot$ Aesthetic ideology $\cdot$ Environmentalism $\cdot$ Sustainable capitalism

\section{Introduction}

Following Wittgenstein's call to imagine law as a way of life (1958), this is a call to envisage environmental law and environmentalism as a way of living beautifully. It employs George Santayana's aesthetic theory $(1896,1905,1910)$ to propose a new paradigm for environmentally engaged citizenship. This call, while new in its intersectional and dialectical approach to law, ideology, and aesthetics, builds on well-known works on the "good citizen" (Schudson 1998); on ethical aesthetic of environmental movements (Leopold, 1966); and works about environmental political activism (Stegner 1980; Carson 2018).

This new paradigm builds on the multifaceted relationship between individuals and their environment. It views environmentally engaged citizenship as a manifestation of individual public subjectivity-or ideology (Neacşu 2020)_through public engagement, demonstrations, voting, or litigating government inaction in cases and controversies

Dana Neacşu

edn13@columbia.edu; neacsue@duq.edu;

dana.neacsu@unibuc.ro

1 The Environmental Science Department, Barnard College, New York City, NY, USA

2 Political Science, University of Bucureşti, Bucharest, Romania

3 Duquesne Law School, Pittsburgh, PA, USA protecting the environment. To this end, as argued here, it proposes an additional manifestation of individual subjectivity, environmental aesthetics.

Legal scholars, such as Frank Grad, have already connected environmental law and aesthetics, when they pointed out the aesthetic damage in conservation litigation.

[P] ublic disregard for aesthetics is a primary flaw in the way we now manage environmental affairs. While we can presumably measure environmental decay in ecological or other technical terms, it is popularly and more obviously evident when things turn ugly; the aesthetic argument is nearly always the most basic cry against development, whether in terms of sight, sound, smell, or taste. ... A government concerned about the welfare of its citizens would be prudent not to deny or disparage the sixth sense whereby men can assess the present or future condition of their environment (Grad 1971, 1543-44).

Along similar lines, on December 28, 1973, signing The Endangered Species Act into law, former President Richard Nixon used the aesthetics of conservation as a standard of good governance. Ironically, in hindsight, nature was perceived as his government's standard of beauty. Preserving threatened wildlife, whether wolves, frogs, snails, or eagles, was Nixon's way to make "America more beautiful" (Nixon 1973, 1027). He stated: 
I have today signed S. 1983, the Endangered Species Act of 1973. At a time when Americans are more concerned than ever with conserving our natural resources, this legislation provides the Federal Government with needed authority to protect an irreplaceable part of our national heritage - threatened wildlife. [...] I congratulate the 93d Congress for taking this important step toward protecting a heritage, which we hold in trust to countless future generations of our fellow citizens. Their lives will be richer, and America will be more beautiful in the years ahead, thanks to the measure that I have the pleasure of signing into law today. (emphasis added) Id.

Because ecological damage is harder to determine and always requires more knowledge and expertise to ascertain, this paper argues for aesthetics to become a driving force behind environmentalism. Few can ever forget Justice Antonin Scalia acknowledging in 2006 during the oral argument in Massachusetts v. EPA (2007), one of the last wins for environmentalists requiring government action to protect clean air, proudly shouting his ecological ignorance while making our rule of law:

Troposphere, whatever.

I told you before I'm not a scientist. [Laughter].

That's why I don't want to have to deal with global warming, to tell you the truth. ${ }^{1}$

From this perspective of understanding human nature as more inclined to intellectual comfort and unchecked display of emotions, political outbursts, and some level of aesthetics, this paper calls for a more-encompassing environmentalism. Usually, engaged citizenship builds on ideological inclinations, where ideology is political subjectivity, individual subjectivity displayed in the public sphere (Neacşu 2020). Additionally, I suggest it theoretically frames environmentally engaged citizenship through a mindful reliance on aesthetics. As Santayana suggested, good governance can take different forms at different times in different circumstances, and there is no reason why environmental conservation today should not suit a Republican as well as a Democratic administration, as it did last century. It is all a matter of harmonizing conflicting interests, Santayana would say.

Theorizing about beauty, from his assumed public position of a spectator-Harvard University academic-Santayana rejoiced exploring the conceptually multifaceted beauty (1896). As Willard Arnett (1989) reminds us, Santayana might have perceived beauty as objectified pleasure, and aesthetics as the gift of finding immediate joy in

\footnotetext{
${ }^{1}$ United States Supreme Court (November 29, 2006). Massachusetts v. Environmental Protection Agency. Oral Argument https://www. oyez. org/cases/2006/05-1120.
}

the obvious. However, Santayana viewed it not separated, but interconnected with morals, as the only way to achieve harmony. "Every artist is a moralist, though he need not preach." $(1922,158)$. Beauty existed for Santayana as a "good," moral value. It incorporated both good governments and nature in its transcendent unifying ability to harmonize opposing interests.

My call relies on Santayana's work because his theoretical matrix adds a new analytical perspective to the complex nature of environmentally engaged citizenship. It illuminates the ambivalence surrounding it, by exposing ugliness, such as redundancy, or outright fraudulent governing. This happens when in a democracy, the government does not govern in the name of, and for the people, but for certain people. It happened during the last few administrations overtly, though with different degrees of transparency, and while relying on different views of aesthetics.

The theoretical framing proposed here will help expose fallacies in judiciary reasoning, which contently cling onto procedural technicalities, a type of formal beauty, at the expense of substantive, redistributive, justice, as required by specific temporary contingencies (Neacşu 2020). To this aim, I will propose an aesthetic and ideological reading of the trial and appellate decisions in Juliana $v$. United States (2016, 2020). As discussed below, this case represents one of the major environmental losses for environmentalists seeking governmental action to protect and conserve nature. Ideologically, the plaintiffs argued for sustainable capitalism (Ghista 2004). Aesthetically, they argued for a particular type of beauty, one that preserved life on the planet. Legally, they asked the government to act responsibly and assert itself as agent of redistributive justice. Eventually, they lost on each front, maybe, as I propose here, because their argument was too foreign and unorthodox, or aesthetically speaking, procedurally too novel, and substantively too abstract.

\section{Environmentalism - the manifestation of aesthetic ideology}

Paraphrasing Santayana (1922a, b), when the governed and governments visualize nature as beautiful and its conservation as good, nature is preserved. When the governors practice good governance, the rise of the oceans can slow down so our planet can begin to heal. I argue that for this to happen, aesthetics need to overcome ideological differences.

Environmentally engaged citizenship reflects environmental ideals, a mixture of various scientific, political, historic, and aesthetic and philosophic theories, molded pragmatically through private and public subjectivity up to the point of purposeful engagement. Climate change activism is one facet of its manifestation. Its engagement with power aims to conserve and thus perpetuate the human epoch, the 
Anthropocene (Baichwal 2019). Its complex nature requires a broad, interdisciplinary analysis because it brings people together, or it could unite them, at all levels of power, even when ideologically their views diverge.

\section{The aesthetic symbolism of environmentalism- Earth Day}

While the Earth was healing itself under the reign of the COVID-19 pandemic (Dutta et al. 2020), on April 22, $2020^{22}$, environmentalists celebrated 50 years since the first Earth Day. Unexpectedly, all they could do was to commemorate its history and its visual magnificence:

In 1970 some 20 million people across the United States, from thousands of schools, colleges, universities and communities, took part in demonstrations,

The New York Times' John Schwartz (2020) credited the power of activism as the fire that sparked the political change at the core of the first Earth Day. Or as Denis Hayes, a graduate student at Harvard in 1969, and the chairman of the First Earth Day better explained how it all started, "the problem [has never been] technological; the problem [was and is] a matter of values." Values, another word for ideals, often are ideologically and aesthetically induced.

More specific, Ralph Nader, a well-known environmentalist, credits Nixon's ecological awareness for the triumph of the First Earth Day. Indeed, Richard Nixon did sign into laws major pieces of environmental legislation. Moreover, the Nixon administration did create the Environmental Protection Agency, the EPA — while, another Republican President, George H. W. Bush was the last president to sign any

\footnotetext{
${ }^{2}$ Even the 50th anniversary of Earth Day, which took place onlinehttps://www.earthday.org/earth- day-2020/-had an aesthetic command. Its activism called for grandeur:

Let's flood the digital landscape with action-Join the global conversations on April 22! (Id.).

marches, environmental cleanups and even a mock trial of automobiles that ended in smashing a car with sledgehammers. New York City closed down parts of Fifth Avenue and 14th Street for its celebration (Schwartz 2020).

${ }^{3}$ Bush took the lead with the other significant piece of domestic legislation he signed while in office: the Clean Air Act Amendments of 1990. [...] Bush also showed his support for the environment by appointing the first professional environmentalist to lead the Environmental Protection Agency (EPA) when he chose William Reilly as its head in 1989. The Clean Air Act Amendments of 1990 built on the first bill passed in 1963 and subsequent bills in 1970 and 1977. The 1990 amendments focused on three aspects of clean air: reducing urban smog, curbing acid rain, and eliminating industrial emissions of toxic chemicals. Although critics were concerned about the cost of the act and its effect on an already weakened economy, President Bush was deeply committed to environmental issues and claimed that by working with the business community to find innovative ways to improve the environment, the economy and the American people
}

environmental bill into federal law. ${ }^{3}$ These environmental statutes allow citizens to sue the government for ecological or aesthetic harms (Cassuto 2004, 90).

Whatever made this unity of ideals between the governed and the governors last century remains commendable. Somehow, the ideal of a clean environment mirrored a private subjectivity many felt comfortable to reveal publicly, whether governors or governed. Using Santayana's view of beauty in government as good government for most, then both Nixon and Bush shared an aesthetic that was pleasing to the governed as well. As shown below, aesthetics seems to be an important constitutive element in politics, as the brief survey or the Obama and Trump years shows, further supporting the aesthetic ideology paradigm this paper proposes.

\section{Political aesthetics and the Obama years}

President Obama's views of governance might be said are a textbook case of Santayana's view of "beauty in the whole": all creatures are instrumental to one another and their "interrelation is no injury to any part and an added beauty to the whole" $(1905,215)$. Though a broken promise, in a President Obama once aimed to have every health care and health insurance interest heard at his negotiating table-suggesting his view of beautiful government was closer to Santayana's.

To achieve health care reform, "I' $m$ going to have all the negotiations around a big table. We'll have doctors and nurses and hospital administrators. Insurance companies, drug companies - they'll get a seat at the table, they just won't be able to buy every chair. But what we will do is, we'll have the negotiations televised on C-SPAN, so that people can see who is making arguments on behalf of their constituents, and who are making arguments on behalf of the drug companies or the insurance companies. And so, that approach, I think is what is going to allow people to stay involved in this process." 4

In the same vein, it can be said that in 2008, environmentalism received a much-needed shot of aesthetics steroids, with a young politician's call to imagine. That call, by Presidential Candidate, Barack Obama, produced a level of dream and information in our citizenry that action became inevitable.

\footnotetext{
Footnote 3 (continued)

could both benefit. Congress passed the bill with significant support, and on November 15, 1990, President Bush signed the act.

Knott, S. (2019) George H. W. Bush: Domestic affairs. https://mille rcenter.org/president/bush/domestic-affairs.

${ }^{4}$ Politifact. https://www.politifact.com/truth-o-meter/promises/ obameter/promise/517/health-care-reform-public- sessions-C-SPAN/
} 
The journey will be difficult. The road will be long. I face this challenge with profound humility, and knowledge of my own limitations. But I also face it with limitless faith in the capacity of the American people. Because if we are willing to work for it, and fight for it, and believe in it, then I am absolutely certain that generations from now, we will be able to look back and tell our children that this was the moment when we began to provide care for the sick and good jobs to the jobless; this was the moment when the rise of the oceans began to slow and our planet began to heal (emphasis added) (Obama 2008).

Obama's speech energized voters. Eventually, voters trusted him and identified with him their ecojustice ideal. Or, vice versa.

In retrospect, that might have happened for reasons other than progressive values. Ideology in the restrictive meaning of ideatic manipulation (Neacşu 2020) might have been its premise, but it does not explain the success of Presidential Candidate Obama. Similarly, ideology as political interpellation of the subject cannot alone explain the success of the candidate and then the popularity of President Obama whose environmental record remained far from top rated.

"President Obama will be remembered for strong leadership on climate change. He implemented two key policies in the United States that will substantially cut the emissions of heat trapping gases - fuel economy standards for vehicles, and limits on carbon dioxide emissions from power plants. He also brokered a deal with China to cut emissions from that country, which is critical to the success of a worldwide agreement expected to emerge in Paris this year. The missing piece of his legacy is national climate change legislation, which he and congress failed to pass."

- Kenneth Kimmell, president of the Union of Concerned Scientists, a nonprofit. ${ }^{5}$

Candidate Obama's success in sharing his ecological ideals is undeniable and it deserves considerable investigation. Santayana's theorizing about the role of aesthetics in politics seems especially useful because, to a certain extent, it can be used to explain both the popularity of President Obama as well as the election of President Trump and Trumpism itself. In The Sense of Beauty, Santayana suggested that the essential right of democracy "is something purely aesthetic" $(1896,85)$. Explaining how our decisions are not necessarily based on knowledge, or even morality (Id., 84), Santayana

\footnotetext{
5 Peak, C. (2015) Here's What 15 Experts Think of President Obama's Record on the Environment. NationSwell https://nationswell. com/15-experts-obamas-environmental-legacy/.
}

then intimated that we choose our governments based on our aesthetics.

Democracy, prized at first as a means to happiness and as an instrument of good government, was acquiring an intrinsic value; it was beginning to seem good in itself, in fact, the only intrinsically right and perfect arrangement (Id.,85).

History proved his intuition right. Our democracy has not changed from one administration to the other based on aspirations of a freer or a more moral government organization, as it happened during the French Revolution, for instance. Obama the candidate was the image of youth and virility, but also wisdom and fatherhood. More likely, the governed opted for that aesthetics to fit their multiplicity. That unifying ground eased in the Democratic Obama administration.

Aesthetics apparently create and outlive political ideals. For instance, while the Obama Administration did not share the ideal of a stable climate of Candidate Obama for a long time, it did project its aesthetic by inhabiting and exuding tolerance and togetherness, prerequisite of natural conservation. The young Democratic administration came around and shared the ideal of climate stability only in the latter part of its second term, and only in a very limited manner. "The Obama presidency would not always meet my early expectations," a scholar reminisces (Kramer), "and on the critical issue of climate change the president often hedged and settled for half- measures" (Kramer 2020, 126).

In the end, for reasons both beyond and under his control, he did not do enough to "slow the rise of the oceans" as he promised that night in St. Paul. Yet, after some early stumbles on the issue, he did develop a climate action plan and create some important policies to try to mitigate carbon emissions. More than any of his predecessors, he seriously addressed the problem of global warming and in his last year in office committed the United States to the historic Paris Agreement-a flawed but solid climate policy legacy. But rather than building on these positive steps, his successor, in one of the greatest climate crimes in history, would attempt instead to roll back these accomplishments and demolish any progress that had been made in responding to the climate crisis (Id.).

There were no environmentally focused legislative acts under either of the Obama administrations. Indeed, during his second administration with a Congress opposed to any environmental regulation, it would have taken much more than political allyship between Democrats and Republicans to have them passed. That is perhaps why only late within his second administration did something happen: The State Department signed the Paris Climate agreement (April 22, 2016). 
Although the government did not fulfill the demands of the governed, the Obama administration appeared as environmentally good. If it had not inculcated, it clearly tolerated environmentally aesthetics as a value, as Santayana would have explained. The ideal of beauty, ergo, good governance, President Obama projected, even as climate litigation flooded the judiciary, survived. The first black administration in the history of the USA surrounded itself if not by tolerance and goodwill, certainly by a new aesthetic: I would argue that black was becoming beautiful, and environmentalism popular. For instance, environmental hope expanded encompassing the belief that the judiciary might find the federal government liable for mismanaging the "res publica" the commons. Juliana $v$. United States, the case discussed in this paper, was filed in 2015.

\section{Political aesthetics and the Trump years}

Juliana $v$. United States was decided in the lower court, in November 2016, while the country was riding the tail end of the Obama's matrix of harmony. United States District Judge Ann Aiken, exercising her "reasoned judgment" in Juliana (2016), applied that particular set of political and juridical aesthetics - she had no doubt that "the right to a climate system capable of sustaining human life is fundamental to a free and ordered society." 6

As a new administration was taking over the reign of the country, and of governmental aesthetics, it became clear that Obama's ecojustice captured an ideal of abstract beauty, which favored preserving nature as necessary for the survival of future generations. To the contrary, Trumpianism was developing its own version of beauty. Its attraction was built on its rarefied, unreachable nature. Trump called climate change and the fight to stabilize it for the sake of a bluer sky tomorrow a "hoax" (Turner 2018). He denied its existence, partly because he could promote a new standard of beauty with mediated access to his private golf courses, manicured to look greener than the wilderness of the destroyed and abandoned commons.

With Trump, our national imaginary discovered that "regal and priestly grandeur" do impress the governed, as Santayana acknowledged in Persons and Places (1944, 164-65). Trump rode formal, acquired, manicured beauty, and pomp more than Republican ideology on his successful ascent to power.

Using different political aesthetics, President Trump, a sort of Melania's Plastic Camelot, brought in an antithetical set of beauty standards (Flanagan 2020). First, Obama's racially inclusive government was being replaced by a racially indifferent government of such aesthetic values as

\footnotetext{
$\overline{{ }^{6} \mathrm{https}: / / \mathrm{www}}$.ourchildrenstrust.org/juliana-v-us.
}

"catching a glimpse of something different" (Arnett 1955, 190). While Obama's political discourse was cogent in its imaginary - remember the call to heal the planet-Trumpianism reveled in what Frankfurt identified as "bullshit" (2005), or "truthiness" (Caron 2021). Nevertheless, both narratives were equally easy to visualize. To Obama's multilayered aesthetics: rarified in their intellectualism but comforting in their maternal projection-Michelle's bare arms were a call for fit mothers from all walks of lives, Trumpian beauty offered the Plastic Camelot (Flanagan 2020). Equally feminine, it remains antithetic to Obama's. Trumpian beauty relies on emaciated models turned First Lady and First Daughter, and on a disparaging discourse of rejection of those who do not fit that particular mold (Shear and Sullivan 2018).

Sanatayana's work clarified the role of aesthetics in government. It also makes it easier to understand how the era of Trumpism was able to so successfully replace the Obama mindset for a large segment of the population. In fact, many Obama and Trump supporters shared similar values: they were more aesthetic than ideological. Obama played the aesthetic subjectivity card, and the governed embraced it relieved. Trumpism, the Obama anti-aesthetics, played its looks to its grotesque end. On January 6, 2021, the Roman centurion-wannabees (the image of the fighter) covered in the American tricolor failed in their attempt to silence governance by any other name but Trump (Fuchs 2021, 250).

Environmentalism cannot be conceived outside the realm of politics. The recent administrations relied heavily on aesthetics as a value to inspire their supporters. As shown below, until recently, environmentalism had a jurisprudential facet: environmental justice was fought in courts. While such a strategy may not be wise with the current Supreme Court, I use Juliana as a case study to show that if "good citizenship" imagines taking the litigation path, then judicial aesthetics need to be considered as much as the ideological contingency of that future moment. Here, judicial aesthetics cover the substantive theory the plaintiffs used to build their case.

\section{Juliana v. United States-epitome of environmentalism and aesthetic ideology}

Juliana, presented as a search for the ideal of ecojustice, captured the imagination of many primarily because of its aesthetics, the youth of its plaintiffs, often referred to as the "children." Juliana (how befitting) is the nickname of a federal lawsuit whose plaintiffs, twenty-one young citizens, from across the USA, with the support of the non-profit Our Children's Trust and Earth Guardians, an environmental organization, filed a constitutional climate change lawsuit against the federal government, on August 12, 2015. 
The suit was filed against the Obama administration, the President, the USA, and federal agencies (collectively, "the government"), which had been replaced by the Trump administration. Aesthetically, the plaintiffs represented the abandoned youth, while the defendants the rapacious, older generation, having failed to do its duty to protect a segment of its citizenry: its youth.

\section{What was the scope of the lawsuit?}

As seen in their filings, ${ }^{7}$ the Juliana plaintiffs alleged a multitude of claims, among them that the federal government's promotion of and support for fossil fuel development violated their Fifth Amendment due process right to a "climate system capable of sustaining human life." This claim requested a declaratory relief.

Plaintiffs also alleged that the federal government had an obligation, as a trustee, to protect public trust resources from despoliation. ${ }^{8}$ Under the atmospheric trust doctrine, the air and atmosphere, like other natural resources, were presented "within the res of the public trust"; with the United States government, their public trustee charged with managing the resources placed in trust for present and future generations. In its role of trustee, plaintiff asserted that the government owed them a fiduciary duty to prevent waste, including "substantial impairment" of the trust resources, while the courts had a duty to enforce the trust obligations. The relief for this clam was injunctive relief-stopping greenhouse gas emissions whose carbon dioxide, produced by burning fossil fuels, were destabilizing the climate system.

Defendants and interveners (industry associations allowed by Magistrate Judge Coffin $)^{9}$ moved to have the complaint dismissed asserting that plaintiffs lacked standing to bring this suit, raised non-justiciable political questions, and they failed to state a constitutional claim. In addition, the movants asserted that the public trust doctrine did not provide a cognizable federal cause of action.

The District Court judge accepted jurisdiction giving plaintiffs the green light to prepare for trial. It denied the government's motion to dismiss, concluding that the plaintiffs had standing to sue, raised justiciable (rather than political) questions, and stated a claim for infringement of a Fifth Amendment due process right to a "climate system capable of sustaining human life" (Aiken, 3-4, 2016).

\footnotetext{
7 Available at http://climatecasechart.com/case/juliana-v-united-state $\mathrm{s} /$ ? $\mathrm{cn}$ - reloaded $=1$.

${ }^{8}$ For more on public trust, see, e.g., Mary Christina Wood's theoretical work, see The Power of the Public Trust Doctrine (2017) https:// thegreeninterview.com/interview/wood-mary-christina/

9 https://www.supremecourt.gov/DocketPDF/18/18A65/54512/20180 717145019412_17A\%20US\%20v\%20US\%20 Dist\%20Ct\%20\%20 $\% 20$ Stay $\% 20$ Appl\%20App.pdf.
}

The court defined that right to be free from catastrophic climate change, and catastrophic climate change as causing "human deaths, shorten human lifespans, result in widespread damage to property, threaten human food sources, and dramatically alter the planet's ecosystem" (Id.). The District Court found that the plaintiffs had stated a viable "danger-creation due process claim" arising from the government's failure to regulate third-party emissions.

This is no ordinary lawsuit ... This lawsuit challenges decisions defendants have made across a vast set of topics - decisions like whether and to what extent to regulate $\mathrm{CO}_{2}$ emissions from power plants and vehicles, whether to permit fossil fuel extraction and development to take place on federal lands, how much to charge for use of those lands, whether to give tax breaks to the fossil fuel industry, whether to subsidize or directly fund that industry, whether to fund the construction of fossil fuel infrastructure such as natural gas pipelines at home and abroad, whether to permit the export and import of fossil fuels from and to the United States, and whether to authorize new marine coal terminal projects. Plaintiffs assert defendants' decisions on these topics have substantially caused the planet to warm and the oceans to rise. They draw a direct causal link between defendants' policy choices and floods, food shortages, destruction of property, species extinction, and a host of other harms (Id.)

\section{What made Juliana "no ordinary suit?"}

From the angle of the aesthetics analysis, in Juliana, the plaintiffs' "environmental imagination" met Judge Aiken's. Formally, this was no ordinary lawsuit (Blumm \& Wood 2017) because of its dual relief: declaratory and injunctive relief, based on defendants' obligation to hold natural resources in public trust. Jedediah Purdy explained environmental imagination as the legal cloak that warps and binds together the "material stuff of land and resources" and the "imaginative devices of religion, aesthetics and rhetoric":

This is not to say, of course, that law is an idealistic enterprise in any straightforward way. Frequently, what law translates is the strength of material interests: the engines of change are land speculators, miners, ranchers, railroads, elite tourists, suburban voters panicked by a poisoning scare. But even those interests are made partly out of ideals: the dignity of the rancher, the sublime experience of the tourist, the ecological picture of nature that helps the suburbanite see a tie between the soil in her backyard and the industrial regulation of the Clean Air Act. Interests are formed by interpretation as much as by brute fact, and so they are shot through 
with ideals. Environmental imagination has always been a blend of the two (Purdy 2015, 229).

Judge Aiken's decision was not an "idealistic enterprise," just because it was beautiful, good, morally, and legally sound, as Santayana would have defined its beauty. Furthermore, Judge Aiken analyzed the children's lawsuit according to the recent United States Supreme Court stare decisis, the Obergefell (2015) precedent. She viewed a parallel between the children's claim to a fundamental liberty right to a "climate system capable of sustaining human life" and Obergefell's reasoning. "Just as marriage is the 'foundation of the family,' a stable climate system is quite literally the foundation 'of society, without which there would be neither civilization nor progress" (Aiken, in Juliana v. U.S., 2016, 31). In other words, the children's claim that "a stable climate is a necessary condition to exercising other rights to life, liberty, and property" was consistent with Obergefell's reasoning, it fits within its legal reasoning. Furthermore, Judge Aiken ignored the defendants' position that the public trust doctrine did not provide a cognizable federal cause of action. Its element of novelty or heterogeneity did not destabilize her view of the rule of law: organizing a living society for the future.

When Judge Aiken rejected the contention that she was deciding beyond a court's competence, "making ad hoc policy determinations about how to weigh competing economic and environmental concerns" (Aiken, 2016, 12), she did not expand the immediate role of the judiciary beyond directing any individual agency to issue or enforce a particular regulation. She manifested the proper role of our courts. With the help of scientists, it is the role of the court to be the fact.

finder, and to "determine what emissions level would be sufficient to redress [plaintiffs'] injuries" (Id., at 18). And once the facts would be established, the Court could declare the United States' current environmental policy infringe their fundamental rights, and subsequently direct the agencies to do their job properly. In Juliana, that meant to conduct a consumption-based inventor of United States $\mathrm{CO}_{2}$ emissions, and use that inventory to "prepare and implement an enforceable national remedial plan to phase out fossil fuel emissions and draw down excess atmospheric $\mathrm{CO}_{2}$ so as to stabilize the climate system and protect the vital resources on which Plaintiffs now and in the future will depend" (Id., 12-13).

\section{Ephemeral beauty}

For two years, the Trump Administration pursued, protracted, and convoluted litigation in the Ninth Circuit and Supreme Court to dismiss the case or to obtain an interlocutory appeal in the Ninth Circuit. Not until both the Ninth Circuit and Supreme Court suggested that an interlocutory appeal was appropriate, Judge Aiken reluctantly agreed to allow an interlocutory appeal in the Ninth Circuit.

It is hard to summarize how vigorously the Trump Department of Justice (DOJ) fought discovery of its energy policy decision related to fossil fuels for the past fifty years.

Briefly, first, DOJ filed a request for interlocutory appeal, a very unusual step as appeals take place after a decision on the merits happens, which Judge Aiken did not issue. A day after, she denied the United States Government's initial request for an interlocutory appeal; the DOJ filed a Ninth Circuit Petition for a Writ of Mandamus and a Request to Stay the proceedings.

The Ninth Circuit denied the DOJ's Petition for a Writ of Mandamus without prejudice: it held that the petition was premature because the Government had failed to demonstrate the "extraordinary circumstances" required for mandamus relief when a party asks an appellate court to review a case before the trial court proceedings have concluded. Though the Ninth Circuit denied the petition, it also suggested that the District Court should consider narrowing the claims before going to trial. The Court of Appeals was "mindful that some of the plaintiffs' claims as currently pleaded [were] quite broad, and some of the remedies the plaintiffs seek may not be available as redress."

Perhaps emboldened by the language in the dismissal, DOJ filed a motion in the United States Supreme Court seeking to stay discovery and halt the trial. The Supreme Court denied the Government's motion without prejudice, but cautioned the District Court that the breadth of respondents' claims is striking, and their justiciability presented substantial grounds for difference of opinion.

Undaunted by this new dismissal, and perhaps emboldened by its language, next, DOJ filed a Petition for a Writ of Mandamus in the Supreme Court, which was again denied without prejudice. The Court though repeated its previous observation regarding the "striking' breath" of the plaintiffs' claims, and noted, "the Government's petition for a writ of mandamus does not have a 'fair prospect' of success in this Court because adequate relief may be available in the United States Court of Appeals for the Ninth Circuit."

In light of the Supreme Court language, the Ninth Circuit granted the Government's renewed Motion for a Temporary Stay of the District Court, delaying the then-scheduled trial before Judge Aiken's court in Eugene, OR. Furthermore, citing both Supreme Court's orders in the case, it requested the District Court to revisit its decisions.

Thus pressured, on November 21, 2018, Judge Aiken finally capitulated. "This Court stands by its prior rulings on jurisdictional and merits issues, as well as its belief that this case would be better served by further factual development at trial." Nevertheless, she felt compelled by the Ninth Circuit's November 8th order and the Supreme Court's July 
30 th and November 2 nd orders in the case to certify the case for interlocutory appeal.

\section{The Ninth Circuit's stance}

On December 26, 2018, the Ninth Circuit, in a divided two to one panel decision, granted the Government permission to take an interlocutory appeal. Chief Judge Thomas and Judge Berzon were in the majority. Judge Friedland filed a dissenting opinion because she read Judge Aiken's order authorizing an interlocutory appeal as actually arguing that such an appeal was inappropriate under 28 U.S.C. $§ 1292$ (b) and that the District Court had only granted the order certifying an interlocutory appeal under compulsion from statements in orders by the Ninth Circuit and the Supreme Court. Accordingly, Judge Friedland would have allowed the case to proceed to trial in the District Court (Mank, 288-92, 2020).

The Ninth Circuit's decision did not address the merits of the case either. To the vigorous fight put up by the government, the Ninth Circuit refused to rule on the constitutional right to a stable climate. As scholars have noted, it only found that plaintiffs had not defendable right to hold the government accountable to come up with a climate change action plan (Craig, 54, 2020). The Ninth Circuit found that the government owed no duty to its citizens to protect their health and welfare from the harm caused because knowingly it approved and promoted the use of fossil fuels, the principal cause of climate disturbance. Aesthetically speaking, the Ninth Circuit did not "see" the children's alleged right, and neither could "see" it infringed, so it refused them their due process of law.

Clearly, the Ninth Circuit disagreed with the lower court's holding in Juliana. While the District Court found the general factual allegation sufficient to withstand a motion to dismiss, the Ninth Circuit disagreed (Juliana, 2020). First, it remained unimpressed with the children's demand for a fundamental right to life for all, including themselves. For instance, Judge Aiken cited U.S. v. Students Challenging Regulatory Agency Procedures, 412 U.S. 669 (1973), for the proposition that standing could not to be denied simply because many people suffered the same injury, but in different degrees. She held that climatic deterioration would affect more the youth, and their fundamental right to life.

While the FAC identifies numerous climatic, meteorological, and political harms that the Earth and its inhabitants will suffer as a result of the government's action and failure to act with respect to $\mathrm{CO} 2$ emissions, the plaintiffs differentiate the impacts by alleging greater harm to youth and future generations (Juliana, 2016, 1268).

The Ninth Circuit disagreed. The Appellate Court found the violation of the youth's expectation "merely speculative" (Juliana, 2020, 21).
Where plaintiffs alleged because carbon dioxide $\left(\mathrm{CO}_{2}\right)$ persisted in the atmosphere, future emissions would lead to severe impacts on children and future generations and the current level of $\mathrm{CO}_{2}$ had already taken our country into the "danger zone"; District Judge Aiken agreed that their interest in the regulation of $\mathrm{CO}_{2}$ level was sufficiently concrete, and counted as an "injury in fact" (2016). To the contrary, the Ninth Circuit held that even if some injuries were concrete (water scarcity had forced some plaintiffs to relocate), a simple declaration that the USA is violating the Constitution would do almost nothing to redress the plaintiffs' concrete injuries (Juliana, 2020, 22).

What for a moment became a rare case of agreeing to go beyond the accepted and expected rules of procedure, or using our aesthetic vocabulary, to see the aesthetic argument beyond the ordinary, proved to be ephemeral. Some would say that the Ninth Circuit had no other option that based on stare decisis, it had its hands tied up. It seems disingenuous. While there was little Supreme Court precedent one way or the other on the exact issues that the Ninth Circuit was confronting in Juliana, there was sufficient stare decisis that the Oregon lower court and the Court of Appeals of the Ninth Circuit cited different Supreme Court precedent in support for their findings.

Both decisions had been overanalyzed. Judge Aiken's decision was hailed as having created history. Climate activists (Lohse 2017) had called the lawsuit "the most important lawsuit on the planet" (Id.), perhaps because it "sought no monetary damages, just solutions, and to hold accountable those who knowingly violated future generations' rights to life, liberty, and property" (Id.).

Its coverage, by a number of major American periodicals, was deeply ideological; the name of the periodical was sufficient to indicate whether the coverage was positive or not. For instance, the National Review's article was rhetorically entitled: Groundbreaking Means Insane? (Whalen 2016).

Scholarly dissertations (Ortiz 2017) had been or were in the process of being written about it. The lawsuit's public importance seemed only to have been heightened by the inauguration of a President who had vocally dismissed climate change as a "hoax" and taken steps to expand domestic fossil fuel production (Id.).

Thus, understandably, Juliana has been held as a deeply consequential lawsuit, and not only for its potential legal outcomes, about subjecting government inaction on climate change to strict scrutiny and compelling the executive branch to adopt a comprehensive climate action plan (Id.). But also, of equal importance, for many scholars was the expectation that Juliana could catalyze a broader transformation in the national imagination of climate change.

Some may say that the Ninth Circuit had very little choice, because a ruling for the plaintiffs would have been doomed in the Supreme Court because it lacked the 5-4 
ideological majority to win. From this perspective, dismissing the lawsuit, the majority on the Ninth Circuit did as little damage as possible under the circumstances. This view is purely ideological. It ignores the possibility advanced here that environmental aesthetics harmonize ideologies. Using Santayana's aesthetic theory, good governance would require the judiciary to address the nefarious effects of governmental inaction on our climate, on our commons, and incorporate Wood's theory of res publica, as applied to the environment (Blumm \& Woods 2017).

Aesthetically speaking, the judiciary would need to choose theories that are novels (Wood's) and potentially welcome jurisprudential challenges. The two Ninth Circuit judges ${ }^{10}$ who wrote the majority opinion reversing and remanding the District Court's found that the legal argument in Juliana challenged their views on standing and environmental damage beyond the ordinary. Such an explanation seems right, if we were to use Massachusetts v. EPA, 549 U.S. 497 (2007), as insight, despite the obvious differences between the two lawsuits.

First, in Massachusetts, petitioners were not children. The adult that started it all, Joe Mendelson, eventually found support from organizations, municipalities, and even some of the Union's states as right holders. That was essential, because the Supreme Court's jurisprudence on standing is more generous with states' rights. Second, the allegations in Massachusetts were statutory and regulatory and limited to the inaction of one particular governmental agency, the Environmental Protection Agency (EPA). The Massachusetts petitioners alleged the agency's illegal failure to regulate the emissions of four gases, including carbon dioxide, under \$202(a)(1) of the Clean Air Act, and the subsequent EPA petition denial, on grounds that it was not authorized to issue mandatory regulations to address global climate change, and even if it had the authority to set greenhouse gas emission standards, it would have been unwise to do because there was no unequivocally established causal link between greenhouse gases and the increase in global surface air temperatures. Their suit was less audacious than the EPA's refusal to act, but not unimaginable from a legal point of view.

\footnotetext{
10 Only Trump appointed more than 150 judges, and. The 9th Circuit in particular, which Trump has railed against as a "big thorn in our side" in the past due to its liberal bent, has seen a dramatic change in its makeup over the past three years, with 10 of its 29 active seats now being held by Trump appointees, and nearly half being held by appointees of Republican administrations.

Blitzer, R. (Dec. 22, 2019) Trump heads into 2020 with 'historic' judicial appointments. Fox News https://www.foxnews.com/politics/ trump-heads-into-2020-with-historic-judicial-appointments.
}

In light of the fact that in Massachusetts, the petitioners did not use any new and novel legal arguments: they hid behind a sovereign state's interest in its coastal land; it begs the question whether the Ninth Circuit's decision (2020) was a defensive response to the bright legal imagination of the children's lawsuit (Pace 2019). Under the Atmospheric Trust Litigation strategy, "the children in Juliana claimed that their fundamental right must be secured and protected by the federal government pursuant to public trust obligations" (Id., at 85). Maybe the Juliana plaintiffs played too large a hand when they asked the courts to consider the planet and its climate res publica, and the government acting as a trustee for them. By asking for redress of a violation of an inchoate fundamental right to life on a planet with a livable climate, the Juliana plaintiffs perhaps introduced an easier possibility of rejection, of their otherwise unthreatening, aesthetically pleasing claim: "[to stop] the planet to warm and the oceans to rise" (Juliana 2016, 4). Maybe its exogenous nature proved more threatening to the legal system than Trumpism to the political system. But then, the judiciary needs to understand that environmental imagination is dynamic (Buell 1995), and it should adapt.

Certainly, ecojustice advocates may argue that like in any suit, the plaintiffs had no choice because they had to show standing: that they had an enforceable right, violated by the defendants' action, and that the court could offer redress. Litigation politics will always carry the day. We will never know why it made sense to ask the courts for both a declaratory relief and to recognize a new fundamental right that "to a stable and healthy climate system, which the United States must actively address and protect via public trust obligations" (ourchildrenstrust.org/Juliana-v-us). A more cautious litigator would have advised the plaintiffs about a two-lawsuit approach. Then, in turn, that could be argued as being an aesthetic choice.

\section{Legal aesthetics}

The final outcome in Juliana proves that aesthetics, like environmental perception (Buell 1995), is dynamic. Moreover, I contend that it is constitutive of the law itself. Juliana might have pushed the ideal of environmental legal aesthetic, or better yet, of aesthetic ideology, but not in a winning manner.

Maybe litigation is too conservative, and has to conform to specific norms, to be the right avenue. In law, conformity is aesthetically pleasing. And only within these parameters can one talk about a procedural sense of beauty, as marked by Massachusetts v. EPA. 
Massachusetts was similar to all other environmental cases that had been decided since Kennedy had joined the Court two decades earlier. In all but one of those cases, Justice Kennedy had sided with the majority. And in many of those instances, he had been the deciding fifth vote. At least in environmental law, but not only then, the way Kennedy went was the way of the Court. That is why some jokingly referred to the Supreme Court as the "Kennedy Court" rather than, as is traditionally done, by the name of the Chief Justice (Lazarus 2020, 183).

Equally interesting is that aesthetic ideologies are determinant. In 2007, it was Justice Anthony Kennedy's year, though it was Justice Antonin Scalia's conservatism that had a stronger element of playfulness, even if limited to belittling or bullying what he perceived to be his ideatic opponents. In Massachusetts, for instance, during oral argument, the attorney arguing for the petitioners needed to carefully settle on the deceptive opening statement, whose 39 words had to assuage the Justices' environmental imagination. As Lazarus mentions (2020), the mere mentioning of climate change as the object of the policy litigated would have totally derailed the argument:

If I may, I'd like to frame the merits very quickly and then turn immediately to standing. Although the case before you arises in an important policy area, it turns on ordinary principles of statutory interpretation and administrative law (Id. at 187- 88).

We will never know why the Ninth Circuit chose to reverse Judge Aiken's decision. But it is a strong possibility, especially in light of our aesthetics analysis, that the Juliana plaintiffs' call for judiciary action was too legally foreign and unorthodox, especially in light of the Trumpian success in changing the composition of our federal judiciary everywhere. ${ }^{11}$ Moreover, if Massachusetts is in any way indicative, the judiciary's desire or ability to confront environmental truth is indeed very limited.

For instance, in 2007, the US Supreme Court proved that it could only entertain truthiness in terms of relief.

\footnotetext{
$\overline{11}$ In his first three years, Trump appointed more than 150 judges, and.

The 9th Circuit in particular, which Trump has railed against as a "big thorn in our side" in the past due to its liberal bent, has seen a dramatic change in its makeup over the past three years, with 10 of its 29 active seats now being held by Trump appointees, and nearly half being held by appointees of Republican administrations.

Blitzer, R. (Dec. 22, 2019) Trump heads into 2020 with 'historic' judicial appointments. Fox News https://www.foxnews.com/politics/ trump-heads-into-2020-with-historic-judicial-appointments.
}

We are not asking the Court to pass judgment on the science of climate change or to order EPA to set emission standards. We simply want EPA to visit the rulemaking petition based upon permissible considerations (Id. at 190).

To the EPA's refusal to perform its duties under delegated authority, adding the Supreme Court of the United States' refusal to direct the EPA to revisit a petition ignored seven years earlier sounds ineffectual, and definitely not close to good governance. Perhaps, the Supreme Court jurisprudence mirrored Justice Scalia, as the most vociferous Justice (Lazarus 2020), who could not, or simply refused to understand the science behind pollution, how carbon dioxide leaving the atmosphere and reaching the troposphere, not the stratosphere, contributed to global warming and by implication, to endangering public welfare. Thus, the Court was spared argument about the fact that a federal agency refused to do its job and regulate greenhouse gas emissions. The Court did not have to hear about greenhouse gas emissions endangering public health and welfare although, by statute, by the will of the People, the EPA was required to restrict greenhouse gas emissions.

To the many other distinctions between Massachusetts and Juliana, in Juliana, the plaintiffs did not seem to consider the proven judiciary inability to grant regulatory relief. The Juliana plaintiffs wanted to change legal standards in environmental litigation. In retrospect, the Ninth Circuit ignored all that work (2020). It treated the lawsuit as a mere Administrative Procedure Act (APA) violation: Did the enumerated agencies violate their duties within the limits imposed on them by the main enabling statute or not? The Ninth Circuit, after having refused a writ of mandamus, eventually went forward with an interlocutory appeal, and held that all defending agencies acted within their legal delegation of powers, and furthermore, the plaintiffs' injury from the dissolution of the Republic had nothing specific, because it "would be felt by all citizens equally" (Juliana, 2020).

As mentioned earlier, some believe that the Ninth Circuit knew that had it not reversed the lower court decision; the plaintiffs would have nevertheless lost, because now, there are three Justices in lieu of the infamous Antonin Scalia, and his loudly spoken words:

[Stratosphere], troposphere, whatever, I told you before I am not a scientist. That's why I don't want to have to deal with global warming, to tell you the truth. (Oral Argument, 2007 ${ }^{12}$ ).

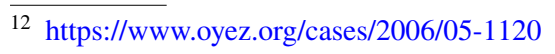


In the process, the Ninth Circuit dismissed the ability to fathom redress for such an undifferentiated harm. It lacked the legal imagination of the dissenter, who, while not offering any "metrics for judicial determination of the level of climate change that would cause 'the willful dissolution of the Republic'," (Juliana, 2020, 30) nevertheless could imagine the confluence of the technical damage with the aesthetic damage. The dissolution of the Republic assumes a tangible and intangible damage: one to the very existence of the subjects of the Republic, and one to the quality of those subjects, to what they consider democratic and worth fighting for and preserving. In the end, whether the Ninth Circuit chose the beauty of ending a particular journey, while choosing to protect its future possibility, or whether it chose the beauty of procedural standing over the foreign substantive of a claim for violations of a res publica on behalf of the youth of America, no one will know. But, what became clear is that Santayana's matrix of unifying interests for the common good could be embraced by governance even in its judiciary aspect: while focused on controversies, the judiciary never has its hands tied, as Judge Aiken's opinion showed.

\section{Environmentally engaged citizenship}

\section{Aesthetic ideology}

Through Santayana's analysis of beauty, we might understand how Juliana became an epitome of ecojustice, and also why it did not last: it satisfied the aesthetics of the governed but not of the governor; or worse, their ideals did not support each other. The plaintiffs represented an archetype of beauty: youth. Their claims sought another type of beauty, a type of climate, and a type of oceans, and atmosphere that would produce a type of blue sky. But how and when did Juliana turn from an ideal of beauty — seeking the Holy Grail of a type of climate-to its opposite, a discardable outcome, reversed, and remanded by the Ninth Circuit-in other words, we can only guess. But perhaps we can figure out using Santayana's theory of beauty how to expand environmental pleasure so it never stops being enjoyable by both rulers and ruled.

The blue sky may come to please chiefly because it seems the image of a serene conscience, or of the eternal youth and purity of nature after a thousand partial corruptions,

Santayana explains how ideals work within our perceptions $(1896,7)$. Such metaphors may carry us to the contemplation of nature, but the question is how to build an ideal of hope to engage our energies to build it. Sure, the outcome is what matters, and aesthetics could be arguably viewed as superior to science if they suffice to embolden action.

Juliana proves that at one point in the environmental justice movement in the USA, a stable climate became desirable (or not threatening) for a significant segment of the ruling class, and their many enablers, and it matched the American people's politics and aesthetics. Paraphrasing Spinoza, as we desire nothing because it is good or beautiful, but it is good and beautiful because we desire it, then what is the key ingredient to inspire both environmental activism and political action?

Juliana also proves that the ideal of a stable climate eventually lost that edge of beauty for the governor, in this case the Ninth Circuit judges. Is there a way to stabilize that? Environmentalism will always represent progressive politics, but its ideology does not need to repel those only interested in the formal beauty of nature. While an indispensable aspect of one's subjectivity-their political subjectivity-ideology is deeply dynamic and influenced by private subjectivity, alienation, education, experiences, and one's gender, race, or sexual orientation, and of course, emotions, and their sense of beauty.

The Circuit Court did not share the lower Court's ideal of beauty "of a blue sky." Worse, the Ninth Court did not see that the youth were being shortchanged by the older generation. That abrupt disdain for life on planet Earth was made possible by many reasons. Ideology could be chief among them.

Ideology, as a concept and as a theory about that concept, has a very political birthdate. Ideology was first defined as a science of ideas by Antoine Desttut de Tracy, an educated nobleman (a count) and a political revolutionary who supported the French Revolution of 1789. Interestingly, de Tracy (1817) identified it as a type of "specialized" knowledge ("true") belonging to the rarefied sphere of intellectuals, or savants, to whom the 1795 Convention entrusted the management of the newly founded Institut de France.

Ironically, at its origins, ideology represented "true knowledge"; it aimed to discover the sources of what we know. Ideology belonged to the first level of knowledge, ontology, if we were to oppose it to other forms of specialized knowledge production, such as epistemology, knowledge about knowledge.

Decades later, Marx also studied ideology, and many of us use the concept loosely based on Marx's views. His position on this topic vacillated, and Marxists often 
misinterpreted it. ${ }^{13}$ Whatever the view, since Marx, ideology has become better defined. It reflected the subject's political values, which set it apart from other systems of belief, such as religion or ethics.

In German Ideology (1846), Marx addressed ideology in a multifaceted way, referring to it epistemologically, in the vein of Destutt de Tracy (1817), but also prefiguring Clifford Geertz's vocabulary (1973), as a political (rather

\footnotetext{
13 Marx's position on ideology has been widely misinterpreted (Barrett 1991). John Torrance (1995) put together an illustrative list of thirteen prominent propositions about ideology that have been wrongly attributed to Marx, indicating to whom each view should be credited:
}

1. Ideology is a psychological process, not a theoretical product (Engels).

2. Ideology is an effect of false consciousness, i.e. ignorance of the real class motives that determine personal motivation (Engels).

3. Ideology is the "top tier" in a model of historical determination of superstructures by the economic base; or alternatively, the entire superstructure is "ideological," but has two levels, the political and the religious, philosophical, etc. or else one level of institutions and another of ideas (Engels, Plekhanov, Kautsky, Althusser, etc.).

4. Whether or not the ideas of a class are ideological depends on whether its ascendancy is functional or dysfunctional for the further development of the productive forces (Kautsky).

5. Ideology is not a critical concept. Ideologies are not distinguished from other non-scientific ideas by the false beliefs they contain, and socialism and Marxism are proletarian ideologies. The working-class movement demonstrates the inferiority of bourgeois ideology either by its ethical superiority (Bernstein) or by its historical success (Lenin).

6. The character of ideology present in a society is explained by its function of promoting interests, and in a class society is explained by the state of the class struggle (Lenin).

7. Class consciousness is explained primarily by the power of the ideologies required by the state of the class struggle (Lenin).

8. False consciousness is class consciousness that does not correspond to the ideology required by a class's historical role (Lenin, Lukacs).

9. Socialist ideology is developed by revolutionary intellectuals quite independently of the development of the workingclass movement (Lenin).

10. The truth of historical materialism is not to be judged by epistemological criteria modeled on the methods of natural science, which are superstructural phenomena reflecting reified consciousness or bourgeois ideology, but it can be vindicated within a dialectical philosophy of praxis (Lukacs, Gramsci).

11. The dominant ideology thesis: the stability of a class society can be explained primarily by the effects of ideology (Gramsci, Marcuse, Althusser).

12. Ideology, like the economy, may or may not be the dominant structure level in a society, and thus secures its social cohesion depending on economic conditions (Althusser).

13. Ideology is both defective and necessary in any human society, even a communist one, to sustain the illusion that the individual "bearers" of social structures are the "subjects" of social action (Althusser). Torrance 1995: 27-28, Neacsu, 89-90 (2020). than cultural) add-on determined by the material intercourse of men. But when Marx became too ludic and posited the qualifier "camera obscura", ${ }^{14}$ Marxian epigones and detractors limited ideology to an optical illusion, as a political distortion of truth. Be it the ultimate meaning of Marxian ideology, one could still argue, as I do, that ideology could have one function individually and a different one socially. Additionally, Marx is a pragmatic theoretician, and rather than discuss ideology conceptually, he focused on its manifestation. While reaching a different position than Marx, I believe that this is the most telling way to understand his views on ideology.

Some agreed that for Marx, ideology expresses the individual's idea about their position vis-à-vis others within the marketplace. Jon Elster developed (1985) this Marxian angle when he contended that ideology is a reflection on human alienation, whether material or intellectual. I agree with Elster's take that ideology reflects on the individual's alienation within the societal web of power. But ideology is formative at a different level than alienation (Neacşu 2020). It interpolates individuals and it actualizes them into political subjects.

Ideology as political subjectivity bolsters environmental activism. It brings the aesthetic ideal of a stable climate into the political arena: politicians implant ideals into our political imaginations and people become politically mobilized. We vote for a president or a political representative in agreement with their views: ideologically, or we do not act against them because of their other values, including those ethical, or aesthetical. Environmental aesthetics might be a barometer of the ideological inclination of an entire nation, and perhaps a lens to understand what citizens are willing to delegate to political representatives or even to government bureaucracies, and what they are willing to engage with themselves. But, within environmentalism, aesthetics and ideology work hand in hand, and perhaps where action is needed one aspect can pull the other to achieve the muchneeded goal: climate action.

\section{Engaged citizenship}

Historically, the development of the institution of citizenship started in the public sphere with the dissemination of writings

\footnotetext{
${ }^{14}$ Men are the producers of their conceptions, ideas, etc.-real, active men, as they are conditioned by a definite development of their productive forces and of the intercourse corresponding to these, up to its furthest forms. Consciousness can never be anything else than conscious existence, and the existence of men is their actual life-process. If in all ideology men and their circumstances appear upsidedown as in a camera obscura, this phenomenon arises just as much from their historical life- process as the inversion of objects on the retina does from their physical life-process.

Marx K. and Engels, Fr. (2001[1846]).The German ideology, 68 (edited and with an introduction by C. J. Arthur) Electric Book Co., London.
} 
on this issue. Like Wells (1995), one might say that without Rousseau's social contract, there would be little basis for citizenship and "citizen" as a legal concept covering rights and duties, though few non-legal scholars mentioned this point. Moreover, scholars (Kelley 1994) have argued that centuries before the French revolution, the English philosophical and legal discourse of Locke made a significant contribution to the development of freedoms, including freedom of thought and access to knowledge for all.

The American concept of citizenship derives from both currents, especially from Lockean liberalism (e.g., Smith 1997). In his study of the USA in the 1830s, de Tocqueville noted (1969[1835/40]) the citizens' active participation in democratic self-governance. He wrote that the American citizens' involvement in public life was viewed as a special duty, which carried personal rewards. In participating in the governing process, people became connected to each other and developed as individuals. The American Revolution extolled this type of citizenship with a legal and ethical dimension, which presumed an individual desire to use and develop new civic virtues, including the one of informed participation in the act of governing.

Republicanism encourages both that citizens participate in the act of governing and that the government represents their will. And as many (e.g., Fritz 1997) have noticed it, since 1776, democracy has been a balancing act of how to determine and realize the will of the people. For Mort Horwitz, this act is derived from the ethos of a society, and not from how its institutions function (1966). Thus, he thinks that threats to freedom cannot be easily overcome by writing more perfect constitutions or laws, as Madison thought, because as Tocqueville noted, in a civilized society, despotism is attained not through torturing its citizens but by eroding their spirit. Or, if despotism were to be established among the democratic nations of our day, it might assume a different character; it would be more extensive and milder; it would degrade men without tormenting them.

Aesthetically, if despotism were to succeed today, it would affect our standards of beauty: from maternal to barren, from inclusive to exclusive, from hopeful civic engagement to disdainful and apocalyptic. When the transition from Obama's politics of hope and inclusion to Trumps' politics of doubt, confusion, and cynicism: the constant attack on reality to adapt it to the needs of the dispossessed not by improving their reality, but offering them a destructive narrative to affect all. When climate change is presented as a hoax and the science behind it ignored, destruction levels the playfield. Ironically, as Hannah Arendt would say in the Origins of Totalitarianism (1951), when citizens' engagement is leveled down to mass engagement and specific political interests with specific end goals are replaced by masses interpellated by cynical perversions of reality, democracy suffers. From this perspective, Trumpism, the aesthetic ideology of negativity, while it has energized masses to levels unseen in American politics, it has damaged democracy everywhere.

Luckily, engaged citizenship is a malleable institution, as the results of the 2020 Presidential Election show: the 2020 election set a voter turnout record. In a referendum of Trumpism, engaged citizens rejected its values. Citizenship encourages democratic civic participation and when supported by the citizens' access to information, a better social contract or compact is achieved. Peter Dahlgren analyzed "civic agency and civic competence" (267-286, 2006), pointing out its vital role in a democracy. Building on this foundation, environmental activism appears as a bridge between agency and competence in achieving ecojustice, or an ideal of climate stability.

Through engaged citizenship, climate stability, an ideal of beauty ideologically colored could become an end goal. It transcends the ethical and the political. And it builds on environmental aesthetics, viewed as a sustainable ideal for everyone to enjoy.

\section{Instead of conclusion}

To most people, Santayana argued:

the stars are beautiful; but if you asked them why, they would be at a loss to reply until they remembered what they had heard about astronomy [...] (Santayana, 64, 1896).

People might offer some other impressive facts they admire and try to remember, but really, we do not understand how it all connects to produce that sensation of beauty and especially acquiescence. We can thus agree on the beauty of nature and derive pleasure from it without too much knowledge, and irrespective of our political views, or despite them. Enjoying nature, we experience complex emotions of beauty influenced ideologically.

Where ideology cannot produce solidarity of vision and action, aesthetics might stimulate our action. Sustainable capitalism, as an era of the Anthropocene, ironically, seems to need civic activism (Atapattu et al. 2020). In Juliana, one may never really know what caused the "primitive accumulation" of dislike, to paraphrase Marx in Capital, vol. 1 (1867, [1887]) ${ }^{15}$ to undo the amazing aesthetic result produced by the lower court's decision. Sometimes a grain of sand inside an oyster produces a pearl, but most of the times it just irritates a fellow dining on oysters. Environmentally engaged citizenship needs to use both situations to preserve what we have for each one and for all of us.

\footnotetext{
15 Marx, K. (1887) Capital. Vol. 1, (Translated: Samuel Moore and Edward Aveling, edited by Frederick Engels) Progress Publishers, Moscow, USSR; https://www.marxists.org/archive/marx/works/downl oad/pdf/Capital-Volume- I.pdf.
} 
Santayana observed that to be successful, no theory can ever end in absolute knowledge of fact (Santayana, 64, 1896). That is why it incorporates images, and it produces concepts with the hope of weaving in a strong imagination able to withhold its mirror into the real world, as well as to protect it from the changes that occur in the real world.

That is probably both hopeful and useful. Because while our intelligence is finite, our will is infinite, as Santayana reminds us Descartes' words. And promoting ideals requires most people's will. To fight climate change requires both our political will and our civic engagement. Armed with a sense of beauty understood as aesthetic ideology, environmentally engaged citizens can promote their ideal in such a manner as to produce the minimal resistance from opponents: emphasizing the pleasure of stability, inclusion, and perpetuity so that opponents cannot disagree with it. In other words, harmonizing interests for the good of the planet, and thus for all of us, we can envisage environmental law and environmentalism as a way of living beautifully.

Acknowledgements Dana would like to thank her students from the Environmental Law, Policy, and Decision-making class (Barnard College/Columbia University), Spring 2020 \& 2021, Environmental Science Department, helmed by Professor Martin Stute, Ph.D., and Brian Mailloux, Ph.D.), Contemporary Civilization - (Columbia University, Spring \& Fall 2021, and Associate Dean and Director of the Center for the Core Curriculum, Larry Jackson, Ph.D.), and the American Governance in the Anthropocene class (Fall 2020, (Universitatea București, Facultatea de Științe Politice/University of Bucharest, Faculty of Political Sciences), under the guidance of Dean, Professor Cristian Preda, $\mathrm{Ph} . \mathrm{D}$.), for their inspirational dedication to scholarship and learning, environmental studies, and civic engagement, as well as Columbia Law Professor-Michael Gerrard, for his unflinching support and guidance of my research, teaching, and scholarship. An earlier version of this article was presented to the WSPA 2020 digital conference at the height of the COVID-19 pandemic. Some of that pathos is still present in these pages: Why don't we all go outside and get ourselves some glory finding meaning and beauty in preserving nature for those coming after us? Peter Bower, you are such an inspiration. Without Izzie, ZouZou, and Absy, little would make sense.

\section{Declarations}

Ethics approval Not applicable.

Consent to participate Not applicable.

Conflict of interest The authors declare no competing interests.

\section{References}

Arendt H (1951) Origins of totalitarianism. Harcourt, Brace and Co., New York

Arnett WE (1989) George Santayana, The sense of beauty: being the outlines of aesthetic theory, critical edition (Book Review).Trans. Charles S. Peirce Soc. 25: 538-545.

Arnett WE (1955) Santayana and the sense of beauty. Indiana University Press: Bloomington
Ashmore J (1966) Santayana, art, and aesthetics. Cleveland Press of Western Reserve University: Cleveland

Atapattu SA et al. (2020) Intersections of environmental justice and sustainable development. Framing the issues in The Cambridge handbook of environmental justice and sustainable (ed. S.A. Atapatt et. Al.) Cambridge University Press, Cambridge

Bahm JA (1947) Beauty defined. Philos Rev 56:582-586

Baichwal J (2019) Anthropocene: the human epoch. A film by Jennifer Baichwal, Nicholas de Pencier, Edward Burtynsky; writer, Jennifer Baichwal; producer, Nicholas de Pencier. Kino Lorber, New York

Blitzer R (2019) (Fox News) Trump heads into 2020 with 'historic' judicial appointments. https://www.foxnews.com/politics/trump heads-into-2020-with-historic-judicial-appointments. Accessed 21 Nov 2021

Blumm M, Wood MC (2017) "No Ordinary Lawsuit": climate change, due process, and the public trust doctrine. Am Univ 1 Rev 67(1):1-87

Buell L (1995) The environmental imagination: Thoreau, nature writing, and the formation of American culture. Belknap Press of Harvard University Press, Cambridge.

Caron JE (2021) Satire as the comic public sphere: postmodern "truthiness" and civic engagement. The Pennsylvania State University Press, University Park.

Carson R (2018) Silent spring \& other writings on the environment (Sandra Steingraber, ed.) The Library of America, New York

Cassuto DN (2004) The law of words: standing, environment, and other contested terms. Harv Envtl 1 Rev 28:79-128

Craig RK (2020) Juliana, climate change, and the constitution. Nat Res \& Env 35:53-55

Dahlgren, P. (2006) Doing citizenship: the cultural origins of civic agency in the public sphere. European J. Cultural Studies 9:267286. https://doi.org/10.1177/1367549406066073

Dutta J et al. (2020) COVID-19 and emerging environmental trends. A way forward. CRC Press, Boca Raton.

Elster J (1985) Making sense of Marx. Cambridge University Press, Cambridge

Flanagan C (2020) Melania's Plastic Camelot. The Atlantic https:// www.theatlantic.com/ideas/archive/2020/10/melania-and-steph anieand-me/616878/. Accessed 21 Nov 2021

Frankfurt HG (2005) On bullshit Princeton. University Press, Princeton

Fritz CG (1997) Alternative visions of American constitutionalism: popular sovereignty and the early American constitutional debate. Hastings Const 1 Quarterly 24:287-357

Fuchs C (2021) How did Donald Trump incite a coup attempt? tripleC: Communication, Capitalism \& Critique. 19(1): 246-251 https://www.triple-c.at/index.php/tripleC/article/download/ $1239 / 1425$

Geertz C (1973) The interpretation of cultures; selected essays. Basic Books, New York

Ghista DN (2004) Socio-economic democracy and the world government [electronic resource] : collective capitalism, depovertization, human rights, template for sustainable peace. World Scientific: Singapore

Grad FP (1971) Law and the environment edited by Malcolm F. Baldwin and James K. Page, Jr., 1970 Colum. L. Rev. 71:1542-48. https://doi.org/10.2307/1121515

Horwitz M (1966) Tocqueville and the tyranny of the majority. Rev Politics 28:293-307 https://www.jstor.org/stable/1405588

Juliana v. U.S., (2016) No. 6:15-cv-1517-TC. https://static1.squar espace.com/static/571d109b04426270152febe0/t/5824e85e6a 49638292ddd1c9/1478813795912/Order+MTD.Aiken.pdf, and F. Supp. 3d 217: 1224-1276 District Oregon, Oregon https://caset ext.com/case/juliana-v-united-states-3. rev'd and remanded, Juliana v. U.S., (2020) Federal Reporter, 3 947:1159-1191 9th Cir., 
https://cdn.ca9.uscourts.gov/datastore/opinions/2020/01/17/1836082.pdf

Kelley DR (1994) Citizenship in the western tradition. American Hist Rev 99:521-522

Knott S (2019) George H. W. Bush: Domestic affairs https://millercent er.org/president/bush/domestic-affairs

Knott S (2019) George H. W. Bush: Domestic affairs https://millercent er.org/president/bush/domestic-affairs

Lazarus RJ (2020) The rule of five: making climate history at the Supreme Court. The Belknap Press of Harvard University Press, Cambridge

Leopold A (1966) A Sand County almanac: with other essays on conservation from Round River Oxford University Press, New York

Lohse D (2017) The most important lawsuit on the planet. Santa Clara Magazine: Sept. 28, 2017. https://magazine.scu.edu/magazines/ fall-2017/the-most-important-lawsuit-on-the-planet/. Accessed 21 Nov 2021

Luke TW (2019) Anthropocene alerts: critical theory of the contemporary as ecocritique Telos Press Publishing, Candor

Mank BC (2020) Can judges use due process concepts in Obergefell to impose judicial regulation of greenhouse gases and climate change?: the crucial case of Juliana v. United States. Belmont 1 Rev 7:277-307

Marx K. and Engels F. (2001[1846]) The German ideology, edited and with an introduction by C. J. Arthur. Electric Book Co., London

Massachusetts v. EPA 549 U.S. 497 (2007) https://www.supremecourt. gov/opinions/06pdf/05-1120.pdf; United States Reports 549:497560 United States Supreme Court

Neacşu D (2020) The bourgeois charm of Karl Marx \& the ideological irony of American jurisprudence Brill, Leiden

Neacşu D (2011) Political satire and political news: entertaining, accidentally reporting or both?: The case of the Daily Show with Jon Stewart (TDS). Thesis (Ph.D.) Rutgers University, New Brunswick. https://doi.org/10.7916/D8959RJ7

Nixon R (1973) Public papers of the presidents of the United States, Washington: Federal Register Division, National Archives and Records Service, General Services Administration, U.S. G.P.O.

Obama B (2008) Transcript - Barack Obama's remarks in St. Paul, New York Times: June 3, 2008. https://www.nytimes.com/2008/06/03/ us/politics/03text-obama.html. Accessed 21 Nov 2021

Obergefell v. Hodges, (2015) https://www.supremecourt.gov/opinions/ 14pdf/14-556_3204.pdf; United States Reports: 576: 644-742 United States Supreme Court

Ortiz, M. (2017) Climate litigation and atmospheric ethics: a case study of Juliana v. United States. The University of North Carolina at Chapel Hill, ProQuest Dissertations Publishing, 10607567 Paris Agreement (April 22, 2016). https://treaties.un.org/doc/Publi cation/MTDSG/Volume\%20II/Chapter\%20XXVII/XXVII-7-d. en.pdf. Accessed 21 Nov 2021

Paris Agreement signature ceremony (April 22, 2016) https://newsr oom.unfccc.int/media/632121/list-of-representatives-to-high-level signature-ceremony.pdf. Accessed 21 Nov 2021

Pace BJ (2019) The children's climate lawsuit: a critique of the substance and science of the preeminent atmospheric trust litigation case, Juliana v. United States Idaho 1 Rev 55:85-114
Purdy J (2015) After nature. A politics for the Anthropocene. Harvard University Press, Cambridge

Santayana G (1896) The sense of beauty; being the outlines of aesthetic theory. C. Scribner's Sons: New York

Santayana G (1905) Reason in art. Harvard University Press: Cambridge

Santayana G (1910) Three philosophical poets. Harvard University Press: Cambridge

Santayana G (1922a) Soliloquiea in England and later soliloquies. C. Scribner's Sons: New York

Santayana G (1922b) The life of reason. C. Scribner's Sons: New York

Santayana, G. (1951) The philosophy of George Santayana (Schilpp, P. A. ed.) Tudor Pub. Co.: New York

Schudson M (1998) The good citizen: a history of American civic life. Martin Kessler Books, New York

Schwartz J (2020) The 'Profoundly Radical' message of Earth Day's first organizer, The New York Times: April 20, 2020. https:// www.nytenis-hayes-earth-day-organizer.htmlimes.com/2020/04/ 20/climate/d

Shear MD, Sullivan E (2018) 'Horseface,' 'Lowlife,' 'Fat, Ugly': how the President demeans women, The New York Times: October 16, 2018, https://www.nytimes.com/2018/10/16/us/politics/trumpwomen-insults.html

Smith R (1997) Civic ideals: conflicting visions of citizenship in U.S. history Yale University Press: New Haven

Starr P (2004) The creation of the media. Political origins of modern communications. Basic Books: Cambridge

Stegner W (1980) Twilight of self-reliance: frontier values and contemporary America. The Tanner Lectures on Human Values delivered at the University of Utah. February 25, $1980 \mathrm{https} / / /$ tannerlect ures.utah.edu/_resources/documents/a-to-z/s/stegner81.pdf

Tocqueville A. de. (1969[1835/40]) Democracy in America (2 vols., ed. J.P. Mayer, trans. G. Lawrence). Doubleday: Garden City

de Tracy, DALC (1817) Élements d'ideologie. 1. Courcier, Paris

Turner, J.M. (2018) The Republican reversal: conservatives and the environment from Nixon to Trump. Harvard University Press, Cambridge

U.S. v. Students Challenging Regulatory Agency Procedures (1973) United States reports 412:669-734. https://tile.loc.gov/storageser vices/service/11/usrep/usrep412/usrep412669/usrep412669.pdf; United States reports 412:669-734 United States Supreme Court

Wells CC (1995) Law and citizenship in early modern France, The John Hopkins University Press, Baltimore

Whalen E (2016) 'Groundbreaking' means 'insane'? National Review, Nov. 21, 2016. https://www.nationalreview.com/bench-memos/ aiken-oregon-climate-change-ruling-juliana/. Accessed 21 Nov 2021

Wittgenstein L (1958) Philosophical investigations, trans. G.E.M. Anscombe. Basil Blackwell, Oxford 